\title{
Hubungan Kadar Hemoglobin Ibu Hamil Trimester III Dengan Berat Bayi Lahir di Kota Pariaman
}

\author{
Anggi Setiawan, Nur Indrawaty Lipoeto, Amirah Zatil Izzah
}

\begin{abstract}
Abstrak
Pendahuluan: Kadar hemoglobin merupakan indikator biokimia untuk mengetahui status gizi ibu hamil. World Health Organization (WHO) merekomendasikan kadar hemoglobin ibu hamil ideal adalah $\geq 11 \mathrm{gr} / \mathrm{dl}$ dan tidak dibawah 10,5 gr/dl pada trimester II kehamilan. Tinggi rendahnya kadar hemoglobin selama kehamilan mempunyai pengaruh terhadap berat bayi lahir karena dapat mengakibatkan gangguan pertumbuhan janin di dalam kandungan. Penelitian ini bertujuan untuk mengetahui hubungan kadar hemoglobin ibu hamil trimester III dengan berat bayi lahir di kota Pariaman. Metode penelitian: design penelitian ini adalah penelitian analitik dengan pendekatan Cross Sectional Study. Penelitian dilakukan di kota Pariaman dengan menggunakan data ibu melahirkan bulan Januari-Juni 2011 dan pengambilan sampel dengan cara consecutive sampling serta data dianalisis dengan uji korelasi Pearson dimana $p<0,05$. Hasil penelitian: ditemukan rata-rata kadar hemoglobin ibu hamil trimester III adalah 11,16 (SD 0,82) gr/dl dan ditemukan ibu hamil yang mengalami anemia sebesar 31,25\%. Rata-rata berat bayi lahir pada penelitian adalah 3.103 (SD 405) gram dan ditemukan bayi yang mempunyai berat lahir rendah sebesar 3,1\%. Kesimpulan: penelitian ini tidak ditemukan adanya hubungan kadar hemoglobin ibu hamil trimester III dengan berat bayi lahir di kota Pariaman $(p>0,05)$
\end{abstract}

Kata kunci: Kadar hemoglobin, berat bayi lahir, ibu hamil

\begin{abstract}
Introduction : Hemoglobin level is biochemical indicator to determine the nutrition status of pregnant women. World Health Organization (WHO) recommends that ideal level of hemoglobin for pregnant women is $\geq 11 \mathrm{~g} / \mathrm{dl}$ and not below $10,5 \mathrm{~g} / \mathrm{dl}$ on the second trimester of pregnancy. Increasing and decreasing of hemoglobin levels during pregnancy influences birth weight because it can cause intrauterine growth disruption. This research is purposed to identify the relation between pregnant woment hemoglobin level on the third trimester of pregnancy and birth weight in Pariaman city. Methods : This research uses analytic research which is using cross sectional design. This research is held on Pariaman city and used pregnant woment data taken from January until June 2011. The results: Research found that an average of pregnant woment hemoglobin level on the third trimester pregnancy is $11,16(S D 0,82) \mathrm{g} / \mathrm{dl}$ and the percentage of pregnant women with anemia $(\mathrm{Hb}<11 \mathrm{gr} / \mathrm{dl})$ is $31,25 \%$. The average of birth weight is 3.103 (SD 405) grams and 3,1\% of total infant have low birth weight. The results of bivariate analysis by using Pearson correlation test is not found the relation between pregnant woment hemoglobin level on the third trimester of pregnancy and birth weight $p=0,856(p>0,05)$. Conclusion: The future research had better has more number of samples and other factors which affect birth weight can be eliminated.
\end{abstract}

Keywords:Hemoglobin level, birth weight, pregnant woment

Affiliasi penulis : Fakultas Kedokteran Universitas Andalas Padang Korespondensi :Anggi Setiawan, Fakultas Kedokteran Universitas Andalas, Jl. P. Kemerdekaan. Padang

\section{Pendahuluan}

Pembangunan dibidang kesehatan tidak bisa dilepaskan dari upaya mewujudkan kesehatan anak sedini mungkin sejak dalam kandungan. Upaya kesehatan ibu telah dipersiapkan sebelum dan selama kehamilan bertujuan untuk mendapatkan bayi yang sehat. Gangguan kesehatan yang terjadi selama kehamilan dapat mempengaruhi kesehatan janin dalam kandungan hingga kelahiran dan pertumbuhan bayi selanjutnya. ${ }^{(3,6)}$

Kekurangan kadar hemoglobin $(\mathrm{Hb})$ ibu hamil merupakan salah satu permasalahan kesehatan yang rentan terjadi selama kehamilan. Kadar $\mathrm{Hb}$ yang kurang dari $11 \mathrm{~g} / \mathrm{dl}$ mengindikasikan ibu hamil menderita anemia. Anemia pada ibu hamil meningkatkan resiko mendapatkan Bayi Berat Lahir Rendah (BBLR), risiko perdarahan sebelum dan saat persalinan, bahkan dapat menyebabkan kematian ibu dan bayinya jika ibu hamil tersebut menderita anemia berat. $\mathrm{Hal}$ ini tentunya dapat memberikan sumbangan besar terhadap angka kematian ibu bersalin maupun angka kematian bayi, dimana berdasarkan SDKI tahun 2007 angka tersebut masih cukup tinggi, yaitu angka kematian ibu (AKI) 228 per 100.000 kelahiran hidup dan angka kematian bayi (AKB) 34 per 1.000 kelahiran hidup. ${ }^{(3,4,8)}$

Kadar hemoglobin merupakan indikator biokimia untuk mengetahui status gizi ibu hamil. Kehamilan normal terjadi penurunan sedikit kon-sentrasi hemoglobin dikarenakan hipervolemia yang terjadi sebagai suatu adaptasi fisiologis di dalam ke-hamilan. Konsentrasi hemoglobin $<11 \mathrm{gr} / \mathrm{dl}$ merupakan keadaan abnormal yang tidak berhubungan dengan hipervolemia tersebut. Ketidakadekuatan hipervolemia yang terjadi malah dapat mengakibatkan tingginya kadar hemoglobin ibu hamil. Kadar hemoglobin ibu hamil yang tinggi juga dapat mengakibatkan gangguan pertumbuhan dan perkembangan janin normal. ${ }^{(1,17,18)}$

Anemia yang terjadi saat kehamilan merupakan salah satu masalah besar yang banyak terjadi di negara berkembang, termasuk Indonesia. Riset Kesehatan Dasar 2007, prevalensi anemia dalam kehamilan adalah sebesar $14 \%$. Beberapa penelitian di Indonesia banyak yang menemukan angka kejadian anemia berkisar $20-80 \%$. Berdasarkan data Laporan Bulanan Kesehatan Ibu dan Anak Dinas Kesehatan 
Provinsi Sumatera Barat tahun 2011, kejadian anemia di provinsi Sumatera Barat adalah sebesar $24,73 \%$. Kejadian anemia di 19 kabupaten/kota di provinsi Sumatera Barat menunjukkan insiden bervariasi. Kota Pariaman merupakan salah satu kabupaten/kota yang mempunyai angka kejadian anemia cukup tinggi yaitu sebesar $30,73 \%$. $^{(5,11)}$

Berat bayi lahir sebagai salah satu indikator kesehatan bayi baru lahir. Berat bayi lahir normal (usia gestasi 37-42 minggu) adalah 2.500-4.000 gram. Berat bayi lahir normal merupakan suatu hal yang sangat penting karena akan menentukan kemampuan bayi untuk dapat menyesuaikan diri terhadap lingkungan hidup yang baru sehingga tumbuh kembang bayi akan berlangsung secara normal..$^{(2,13,16)}$

BBLR merupakan salah satu dampak tidak sempurnanya tumbuh kembang janin selama di dalam rahim ibu. BBLR adalah bayi yang mempunyai berat lahir kurang dari 2.500 gram yang ditimbang pada saat lahir sampai dengan 24 jam pertama setelah lahir. BBLR mempunyai resiko morbiditas dan mortalitas yang tinggi. Berdasarkan data Depkes RI tahun 2003 yang dilihat dari pola penyebab kematian neonatal, proporsi penyebab kematian neonatal kelompok umur 0-7 hari tertinggi adalah akibat prematur dan berat badan lahir rendah (35\%), kemudian asfiksia lahir $(33,6 \%) .(4,7,10)$

Prevalensi BBLR di Indonesia, khususnya di provinsi Sumatera Barat sendiri sangat bervariasi diantara satu daerah dengan daerah lainnya. Laporan Bulanan Kesehatan Ibu dan Anak Dinas Kesehatan Provinsi Sumatera Barat tahun 2011 mendapatkan bahwa angka BBLR di provinsi Sumatera Barat adalah sebesar $1,9 \%$. Kota Pariaman merupakan salah satu kabupaten/kota yang mempunyai prevalensi cukup tinggi yaitu sebesar $2,55 \%$.

Hingga saat ini di Indonesia sudah terdapat beberapa penelitian yang mencoba untuk mencari hubungan antara kadar hemoglobin ibu hamil dengan berat bayi lahir. Suatu penelitian cohort prospective di kota Semarang saat trimester III kehamilan menemukan bahwa terdapat hubungan yang bermakna antara kadar hemoglobin ibu hamil dengan berat bayi lahir. Trimester III kehamilan memang merupakan masa dimana terjadinya pertumbuhan janin yang lebih cepat dibandingkan trimester sebelumnya. ${ }^{(1,9)}$

Penelitian ini bertujuan untuk mengetahui hubungan kadar hemoglobin ibu hamil trimester III dengan berat bayi lahir di kota Pariaman.

\section{Metode}

Penelitian dilakukan di kota Pariaman pada bulan Oktober 2011 sampai September 2012. Sampel dalam penelitian ini sebanyak 32 orang. Sampel me-rupakan ibu hamil yang melahirkan secara normal dengan bidan yang telah bekerja sama dalam peneliti Nur Indrawaty Lipoeto dan kawan-kawan di kota Pariaman pada bulan Januari-Juni 2011 yang memenuhi kriteria inklusi dan tidak memiliki kriteria eksklusi. Metode pengambilan sampelnya adalah dengan cara consecutive sampling. Instrument penelitian yang digunakan adalah kuesioner untuk pengisian identitas responden, timbangan khusus bayi (baby scale) yang mempunyai ketelitian $0,1 \mathrm{~kg}$, dan peralatan untuk pengukuran kadar hemoglobin dengan metode cyanmethemoglobin. Data yang diperoleh diolah dengan software computer yaitu SPSS, dan untuk analisis hasil penelitiannya digunakan uji korelasi Pearson dengan tingkat pemaknaan $p<0,05$. $^{(19)}$

\section{Hasil dan Pembahasan}

a. Kadar Hemoglobin Ibu Hamil Trimester III

Tabel 1: Distribusi Frekuensi Subjek Penelitian Berdasarkan Kadar Hemoglobin Trimester III

\begin{tabular}{ccc}
\hline $\begin{array}{c}\text { Kadar } \\
\text { Hemoglobin }\end{array}$ & Frekuensi & $\begin{array}{c}\text { Persentase } \\
(\%)\end{array}$ \\
\hline$<11 \mathrm{gr} / \mathrm{dl}$ & 10 & 31,25 \\
$\geq 11 \mathrm{gr} / \mathrm{dl}$ & 22 & 68,75 \\
Total & $\mathbf{3 2}$ & $\mathbf{1 0 0}$ \\
\hline
\end{tabular}

Berdasarkan tabel 1 dapat dilihat bahwa ibu hamil yang kadar hemoglobinnya $(\mathrm{Hb})<11 \mathrm{gr} / \mathrm{dl}$ dan dikategorikan sebagai anemia sebanyak $31,25 \%$. Hal ini mendukung data Laporan Bulanan Kesehatan Ibu dan Anak Dinas Kesehatan Provinsi Sumatera Barat 2011 yang menemukan bahwa insiden anemia di Pariaman lebih tinggi dari rata-rata kejadian anemia di propinsi Sumatera Barat yang hanya sebesar $24,73 \%$.

Penelitian ini didapatkan kadar hemoglobin ibu hamil trimester III terendah adalah sebesar 8,9 gr/dl dan tertinggi sebesar $13,1 \mathrm{gr} / \mathrm{dl}$. Rata-rata kadar hemoglobin ibu hamil trimester III pada penelitian adalah $11,16($ SD 0,82) $\mathrm{gr} / \mathrm{dl}$.

\section{b. Berat Bayi Lahir}

Tabel 2: Distribusi Frekuensi Subjek Penelitian Berdasarkan Berat Bayi Lahir

\begin{tabular}{ccc}
\hline $\begin{array}{c}\text { Berat Bayi } \\
\text { Lahir }\end{array}$ & Frekuensi & $\begin{array}{c}\text { Persentase } \\
(\%)\end{array}$ \\
\hline$<2.500$ gram & 1 & 3,1 \\
$\geq 2.500$ gram & 31 & 96,9 \\
Total & $\mathbf{3 2}$ & $\mathbf{1 0 0}$ \\
\hline
\end{tabular}

Berdasarkan table 2. dapat dilihat bahwa ditemukan $3,1 \%$ bayi yang dilahirkan memiliki berat lahir < 2.500 gram dan dikategorikan BBLR, sedangkan $96,9 \%$ bayi lagi dilahirkan dengan berat $\geq 2.500$ gram.

Penelitian ini didapatkan berat bayi lahir terendah dari ibu hamil yang dijadikan sebagai subjek pada penelitian adalah 2.000 gram dan tertinggi adalah 4.000 gram. Rata-rata berat bayi lahir pada penelitian ini adalah 3.103 (SD 405) gram.

c. Hubungan Kadar Hemoglobin Ibu Hamil Trimester III dengan Berat Bayi Lahir

Tabel 3: Hasil Analisis Hubungan Kadar Hemoglobin Ibu Hamil Trimester III dengan Berat Bayi Lahir

\begin{tabular}{c|ccc}
\hline & & $\boldsymbol{r}$ & $\boldsymbol{p}$ \\
\cline { 3 - 3 } Kadar Hb & Berat & $+0,033$ & 0,856 \\
Ibu Hamil & Bayi & & \\
Trim III & Lahir & & \\
\hline
\end{tabular}

Tabel 3 dapat dilihat bahwa hasil analisa uji statistik menggunakan uji korelasi Pearson pada penelitian ini mendapatkan nilai koefisien korelasi Pearson ( $r$ ) 
sebesar $+0,033$, yang menunjukkan derajat hubungan yang sangat lemah dengan tarif signifikansi $(p)$ 0,856 $(p>0,05)$. Dari hasil analisa uji statistik tersebut dapat disimpulkan bahwa tidak terdapat hubungan signifikan antara kadar hemoglobin ibu hamil trimester III dengan berat bayi lahir.

Hubungan kadar hemoglobin trimester III dengan berat bayi lahir memang telah dilaporkan pada beberapa penelitian. Kadar hemoglobin ibu hamil trimester III yang rendah dan tinggi dapat mengakibatkan pertumbuhan janin terhambat/kecil untuk masa kehamilan. ${ }^{(12,20)}$ Pada penelitian ini, peneliti belum bisa menemukan hubungan antara kadar hemoglobin ibu hamil trimester III dengan berat bayi lahir tersebut. Menurut asumsi peneliti, hal ini terjadi karena masih adanya faktor-faktor lain yang mempengaruhi berat bayi lahir yang belum dapat disingkirkan sebagai faktor perancu pada penelitian.

Pada dasarnya, berat bayi lahir memang tidak mutlak dipengaruhi oleh kadar hemoglobin ibu hamil. Berat bayi lahir dipengaruhi oleh dua faktor ibu yang mempengaruhi pertumbuhan janin intrauterin, yaitu faktor internal dan eksternal ibu hamil. Kadar hemoglobin termasuk ke dalam faktor internal ibu hamil. ${ }^{(14)}$

Faktor internal ibu hamil, tidak hanya kadar hemoglobin ibu hamil yang dapat mempengaruhi berat bayi lahir, tetapi juga dipengaruhi usia ibu, paritas, jangka waktu kehamilan, jarak kehamilan, status gizi, penyakit selama kehamilan, dan faktor genetik. Faktor eksternal, kebiasaan hidup ibu hamil, karakteristik asuhan antenatal, dan keadaan sosial ekonomi keluarga juga turut mempengaruhi pertumbuhan intrauterin sehingga juga berdampak terhadap berat bayi lahir.

Penelitian ini tidak semua faktor-faktor yang mempengaruhi berat bayi lahir tersebut dapat disingkirkan sebagai faktor perancu penelitian. Dari faktor internal, seperti jarak kehamilan, status gizi, dan faktor genetik masih belum bisa disingkirkan sebagai faktor perancu penelitian. Begitu juga dengan penyakit-penyakit selama kehamilan yang dapat mempengaruhi berat bayi lahir rendah maupun berlebih. Penelitian ini peneliti hanya menyingkirkan hipertensi gestasional sebagai penyakit selama kehamilan yang mempengaruhi berat bayi lahir, sedangkan penyakit infeksi selama kehamilan dan diabetes mellitus gestasional masih menjadi faktor perancu. Padahal ibu hamil yang mengalami diabetes mellitus gestasional dapat meningkatkan resiko terjadinya berat bayi lahir berlebih pada janin yang dikandung.

Kebiasaan hidup ibu hamil dan keadaan sosial ekonomi keluarga sebagai faktor eksternal ibu hamil yang turut mempengaruhi berat bayi lahir juga belum bisa disingkirkan sebagai faktor perancu dalam penelitian ini. Status sosial ekonomi mempunyai tanggung jawab yang cukup besar terhadap berat bayi lahir karena bertanggung jawab terhadap nutrisi yang dikonsumsi ibu hamil, asuhan antenatal yang memadai, dan timbul komplikasi selama kehamilan. ${ }^{(15)}$

\section{Kesimpulan}

Berdasarkan penelitian yang telah dilakukan, dapat ditarik kesimpulan bahwa :

1. Rata-rata kadar hemoglobin ibu hamil trimester III adalah 11,16 (SD 0,82) gr/dl dan ditemukan ibu hamil yang mengalami anemia sebesar $31,25 \%$.
2. Rata-rata berat bayi lahir adalah 3.103 (SD 405) gram dan ditemukan bayi yang mempunyai berat lahir rendah sebesar 3,1\%.

3. Tidak ditemukan adanya hubungan kadar hemoglobin ibu hamil trimester III dengan berat bayi lahir di kota Pariaman $(p>0,05)$.

\section{Daftar pustaka :}

1. Cunningham FG dkk. Adaptasi ibu terhadap kehamilan \& Gangguan pertumbuhan janin. Dalam : Hartanto H dkk (editor). Obstetri Williams vol 1. Edisi 21. Jakarta : EGC; 2006. hlm. 180218; 825-50.

2. Damanik SM. Klasifikasi bayi menurut berat lahir dan masa gestasi. Dalam : Kosim MS, Ari Y, Rizalya D, Gatot IS, Ali U. Buku ajar neonatologi. Edisi 1. Jakarta : Ikatan Dokter Anak Indonesia; 2010. hlm. 11-29.

3. Departemen Kesehatan RI. Profil kesehatan Indonesia. Jakarta : Depkes RI; 2009.

4. Departemen Kesehatan RI. Profil kesehatan Indonesia. Jakarta : Depkes RI; 2008.

5. Departemen Kesehatan RI. Laporan hasil riset kesehatan dasar (RISKESDAS INDONESIA 2007). Jakarta : Depkes RI; 2008.

6. Departemen Kesehatan RI. Pedoman pelaksanaan stimulasi, deteksi, dan intervensi dini tumbuh kembang anak di tingkat pelayanan kesehatan dasar. Jakarta : Bakti Husada; 2006.

7. Departemen Kesehatan RI. Penyakit penyebab kematian bayi baru lahir (neonatal) dan sistem pelayanan kesehatan yang berkaitan di Indonesia. Jakarta : Depkes RI; 2003.

8. Departemen Kesehatan RI. Pedoman umum gizi seimbang (panduan untuk petugas). Jakarta : Depkes RI; 2002.

9. Fidranti DY. Hubungan pertambahan berat badan, kadar hemoglobin, tingkat asupan asam folat, dan seng ibu hamil pada trimester II dan III dengan berat bayi lahir di puskesmas Ngesrep dan Pandanaran Semarang (artikel penelitian). Semarang : Universitas Diponegoro; 2007.

10. Kliegman RM. Bayi beresiko tinggi. Dalam : Behrman RE, Robert K, Ann MA. Ilmu kesehatan anak Nelson ed 15 vol 1. Jakarta : EGC; 2000. hlm. 558-73.

11. Kusumah UW. Kadar hemoglobin ibu hamil trimester II-III dan faktor-faktor yang mempengaruhinya di RSUP $H$. Adam Malik Medan (tesis). Medan: Universitas Sumatera Utara; 2009.

12. Makhoul Z. Anemia and iron deficiency in rural nepali pregnant women : risk factors, effect of vitamin A supplementation and their association with birth outcomes (dissertation). University of Arizona; 2007.

13. Moehyi S. Bayi sehat dan cerdas melalui gizi dan makanan pilihan : pedoman asupan gizi untuk bayi dan balita. Jakarta : Pustaka Mina; 2008.

14. Nurkhasanah. Hubungan status protein, besi, seng, vitamin $\mathrm{A}$, folat dan antrophometri ibu hamil trimester II dengan bayi berat lahir rendah (tesis). Semarang : Universitas Diponegoro; 2003.

15. Sachdeva P, Patel BG, Patel B, Bhatt M. A Study of factors affecting birth weight. Journal of global pharma technology. 2010; 118-23.

16. Saifuddin AB, George A, Gulardi HW, Djoko W. Buku acuan nasional pelayanan kesehatan 
pregnant woment dan neonatal. Jakarta : JNPKKR-POGI; 2002.

17. Steer PJ. Pregnant woment hemoglobin concentration and birth weight. Am J Clin Nutr. 2000; 71(5) : 1285-7.

18. Suharto $A$, Subagyo, Supriasih. Hubungan antara ukuran LLA, kenaikan BB selama kehamilan, dan kadar $\mathrm{Hb}$ dengan berat bayi lahir di wilayah kerja desa Gerih kec Gerih kab Ngawi. Jurnal penelitian kesehatan suara forikes. 2012; 3(2) : 103-11.
19. Tumbelaka AR dkk. Pemilihan uji hipotesis. Dalam (Sastroasmoro S, Sofyan I). Dasar-dasar metodologi penelitian klinis ed 2. Jakarta : CV Sagung Seto; 2002. hlm. 240-58.

20. Wang $J$ dkk. Study on the third trimester hemoglobin concentrations and the risk of low birth weight and preterm delivery. PubMed. 2007; 28(1) : 15-8. 